\title{
Food from heaven
}

Roy Porter

From Fasting Saints to Anorexic Girls. The History of Self-Starvation. By Walter Vandereycken and Ron van Deth. Athlone/New York University Press: 1994. Pp. 296. £18.95, \$42.50 (hbk); $\$ 17.95$ (pbk).

THOSE seeking historical perspectives on the present epidemic of eating disorders have been well-served by recent historians - the books of Joan Jacobs Brumberg, Rudolph Bell and Hillel Schwartz come especially to mind. This study by two Dutch psychiatrists is a valuable addition to attempts to elucidate a tragic problem.

Choosing the wide-angle lens - their study proceeds from Antiquity to the present, covering the Old World and the New - Vandereycken and van Deth have wisely avoided the reductionist trap of medicalizing the past. Although noting the antiquity of the medical term 'anorexia' (literally, absence of appetite), they disclaim the psychiatrically tempting supposition that all selfstarvers in the past have been afflicted by a clinical disorder - in other words, they might be retrospectively diagnosed as anorexic. Instead, they strive to lay bare the meanings of earlier self-starving behaviour, while exploring the advent of anorexia nervosa, that is, the moment at which strange eating habits fell under medical and, above all, psychiatric scrutiny.

The authors propose a threestage history. Early self-starvation was characteristically conducted within a religious agenda whose goal was the mortification of the flesh. All Christians were to renounce the deadly sin of gluttony and to fast as directed by the Church. But Desert Fathers and hermits pursued food asceticism on an heroic scale, undergoing prolonged fasting or supping on nothing but locusts and grass; some female saints pursued particularly pious food preferences, refusing all food but the Host.

While perfecting holy abstinence, mediaeval Catholicism recognized its perils: fasting unto death was the ultimate sin of suicide, and in any case such austerities might not be piety but vanity or even the promptings of the devil. It comes as no surprise, therefore, that Protestantism was vigorously dismissive of such superstitious balderdash, and, partly for that reason, the era of spiritual fasting gave way to a period of fascination with starvation as spectacle. The eighteenth and nineteenth centuries promoted the faster as freak, a local curiosity for ghouls to swarm around or an object of commercial exploitation alongside midgets and bearded ladies in fairs and circuses. Protégés of $\mathrm{P}$. T. Barnum achieved great celebrity as hunger artists, staging grand public fasts in theatres before a voyeuristic public, titillated by such feats of selfdenial and macabre skeletal displays.

It was at this stage that the involvement of the medical profession intensified.

deviance. But from the 1850 s, more specialized psychiatric terms began to be coined: anorexie nerveuse, anorexie gastrique and so on.

As is well known, a priority dispute erupted around 1870 between (Sir) William Gull and the French neuropsychiatrist, Ernest Lasègue, as to who had first deployed the term anorexia nervosa in its full clinical sense. Vandereycken and van Deth incline to Lasègue, but insist that such priority questions are trivial matters in contrast to the telling fact that from around the 1870 s the historian can at last without anachronism speak about the presence of the anorexia syndrome. In other words, by then there were not merely fasting people, but self-starvers with personality dispositions recognizably akin to the classic anorectics of the postwar period.

And herein lies the conceptual thrust of this intelligently argued (and admirably translated) work. It is not helpful, the authors claim, to label ancient self-starvers 'anorectics' because their mindsets and behaviours were essentially dissimilar from the modern paradigm: in the Middle Ages at least, fasting was an act of orthodox piety not of personal rebellion. Above all, 'slimness' was a goal unknown before emaciation and emancipation became linked in modern feminism.

So Vandereycken and van Deth's contention is that although anorexia nervosa is indeed a psychiatric disorder, it is one that cannot be parcelled up in a reductionist manner, isolated from the wider social systems and cultural beliefs that provide its roots and afford its meanings. Moreover, unlike some recent feminist writers, they maintain that no rivalry The thirteenth-century Saint Hedwig of Silesia, who dieted solely on fish, bread, vegetables, milk and water (1504).

Occasionally physicians would authenticate these great exhibitions of emaciation, but most often they intervened as sceptics, vociferously denying the physiological possibility that marvellous maids might survive for years on nothing but sips of whey, or even the air, and so serving as fraud-busters.

But this inescapably led to the third stage. For when these public-spirited exposés failed to put a salutary end to the fasting fad, the doctors had no alternative but to pronounce the whole palaver not, after all, just an arrant swindle but a sickness in its own right. The self-starvers (characteristically female) were not so much cheats as ill - sick in body but above all in mind. Initially the label affixed with gay abandon from early Victorian times was 'hysterical'; hysteria had, after all, become the portmanteau diagnosis for female perversities of the will and expressions of social and sexual should be assumed between the 'disease' and the 'protest' models. Rather, modern anorexia is the biopsychosocial disorder that mirrors a society with tensions and contradictions: the bourgeois family, supportive but suffocating, and all the paradoxical hypocrisies of attitudes towards youth, food, beauty and sexuality, exploited by the media and affluence industries.

And even as we begin to grasp anorexia, it may be fading away in front of our very eyes, transforming itself in a protean manner into new and hitherto little understood disorders of consumer society. Meanwhile, Vandereycken and van Deth have contributed not a little to our comprehension, and deserve our thanks for a well-researched work that shows how history and psychiatry may be allies.

Roy Porter is in the Wellcome Institute for the History of Medicine, 183 Euston Road, London NW1 1BN, UK. 